\title{
Pro-angiogenic effects of pregnancy-specific glycoproteins in endothelial and extravillous trophoblast cells
}

\author{
Shemona Rattila ${ }^{1}$, Florian Kleefeldt ${ }^{2}$, Angela Ballesteros ${ }^{3}$, Jimena S Beltrame ${ }^{4}$, Maria L Ribeiro ${ }^{4}$, \\ Süleyman Ergün² and Gabriela Dveksler ${ }^{1}$ \\ ${ }^{1}$ Department of Pathology, Uniformed Services University of Health Sciences, Bethesda, Maryland, USA, ${ }^{2}$ Institute \\ of Anatomy and Cell Biology, Julius-Maximilians-University Würzburg, Würzburg, Germany, ${ }^{3}$ Molecular Physiology \\ and Biophysics Section, National Institute of Neurological Disorders and Stroke, National Institutes of Health, \\ Bethesda, Maryland, USA and ${ }^{4}$ Laboratory of Physiology and Pharmacology of Reproduction, Centre for \\ Pharmacological and Botanical Studies (CONICET - School of Medicine, University of Buenos Aires), Buenos \\ Aires, Argentina
}

Correspondence should be addressed to G Dveksler; Email: gabriela.dveksler@usuhs.edu

\begin{abstract}
We previously reported that binding to heparan sulfate (HS) is required for the ability of the placentally secreted pregnancy-specific glycoprotein 1 (PSG1) to induce endothelial tubulogenesis. PSG1 is composed of four immunoglobulin-like domains but which domains of the protein bind to HS remains unknown. To analyze the interaction of PSG1 with HS, we generated several recombinant proteins, including the individual domains, chimeric proteins between two PSG1 domains, and mutants. Using flow cytometric and surface plasmon resonance studies, we determined that the B2 domain of PSG1 binds to HS and that the positively charged amino acids encompassed between amino acids 43-59 are required for this interaction. Furthermore, we showed that the B2 domain of PSG1 is required for the increase in the formation of tubes by endothelial cells (EC) including a human endometrial EC line and two extravillous trophoblast (EVT) cell lines and for the pro-angiogenic activity of PSG1 observed in an aortic ring assay. PSG1 enhanced the migration of ECs while it increased the expression of matrix metalloproteinase-2 in EVTs, indicating that the pro-angiogenic effect of PSG1 on these two cell types may be mediated by different mechanisms. Despite differences in amino acid sequence, we observed that all human PSGs bound to HS proteoglycans and confirmed that at least two other members of the family, PSG6 and PSG9, induce tube formation. These findings contribute to a better understanding of the pro-angiogenic activity of human PSGs and strongly suggest conservation of this function among all PSG family members.

Reproduction (2020) $\mathbf{1 6 0} 737-750$
\end{abstract}

\section{Introduction}

Placental angiogenesis, which is first observed in the decidua in proximity of the implantation site, is necessary to ensure fetal growth (Reynolds \& Redmer 2001, Berndt et al. 2006, Chen et al. 2017). Maternal vascular malperfusion is found in diseases of pregnancy, including severe pre-eclampsia and fetal growth restriction, underscoring the importance of proper angiogenesis for a successful pregnancy (Mayhew et al. 2004, Redman \& Sargent 2005, Reynolds et al. 2006). Therefore, it is important to understand the factors that modulate the angiogenesis process during pregnancy, as some of the deregulated factors could be candidates for therapeutic intervention or can be used as biomarkers aiding in early diagnoses (Torry et al. 2007, Sokolov et al. 2017).

Pregnancy-specific glycoproteins (PSGs) are secreted by syncytiotrophoblasts and extravillous trophoblasts
(EVTs) into the maternal circulation in species with hemochorial placentation (Bohn 1971, Roberts et al. 2016, Rattila et al. 2019). PSG expression is first observed in the blastocyst and expression rapidly increases, with concentrations of $200 \mu \mathrm{g} / \mathrm{mL}$ in the third trimester (Towler et al. 1976, Dimitriadou et al. 1992, Zhou et al. 1997a, Aronow et al. 2001, Camolotto et al. 2010). PSG-expressing species have multiple PSGencoding genes; 11 in humans, 15 in baboons, and 17 in mice (Zhou \& Hammarstrom 2001, McLellan et al. 2005). PSG1 is the best studied of the ten human PSGprotein encoding genes (Wurz et al. 1981, Teglund et al. 1994, Zhou \& Hammarstrom 2001, Shanley et al. 2013, Moore \& Dveksler 2014).

To date, several ligands have been described for PSG1, some of which are shared by other members of the human and murine PSG families (Martinez et al. 2013, Shanley et al. 2013, Moore \& Dveksler 2014, Warren et al. 2018, Rattila et al. 2019). PSGs bind to 
the latency-associated peptide (LAP) of TGFB1, inducing the activation of the latent form of this cytokine and, through this action, likely contribute to the establishment of tolerance to the semi-allogeneic fetus (Blois et al. 2014, Warren et al. 2018). In addition, PSG1, PSG9, and murine PSG23 were shown to bind to $\alpha \operatorname{llb} \beta 3$ and inhibit the interaction of this integrin with fibrinogen (Shanley et al. 2013). Furthermore, PSG1 modulates the adhesion and migration of EVTs by binding to integrin $\alpha 5 \beta 1$ (Rattila et al. 2019).

Besides the proposed functional roles of PSGs described above, previous studies indicated that PSG1 also has pro-angiogenic functions but whether this activity is conserved in other PSGs and which domain(s) of the protein is required for this action was not explored (Ha et al. 2010, Lisboa et al. 2011).

The vasculature in adults is rather quiescent with the exception of pregnancy and the menstrual cycle in which non-pathological angiogenesis is observed (Rizov et al. 2017). Locally elevated pro-angiogenic growth factors (GFs) and cytokines are present at the site of implantation and placentation and together with products of the syncytiotrophoblasts tip the balance toward angiogenesis (Fraser \& Lunn 2000, Islami et al. 2003, Cole 2009). We proposed that PSGs participate in the regulation of maternal angiogenesis by inducing the secretion of VEGF-A by monocytes and EVTs and by binding to the heparan sulfate (HS) moiety of heparan sulfate proteoglycans (HSPG) (Ha et al. 2010, Lisboa et al. 2011). PSG1 induced endothelial tubulogenesis by primary dermal microvascular ECs and also by porcine aortic ECs, which lack the VEGF kinase insert domain receptor, indicating that VEGF-A is not essential for this activity of PSGs in ECs (Ha et al. 2010, Lisboa et al. 2011). In addition, we determined that PSG1 did not induce VEGF-A in the ECs tested but synergized by VEGF-A in its ability to induce tube formation ( $\mathrm{Ha}$ et al. 2010, Lisboa et al. 2011). Studies to identify PSG1 receptors that could be involved in its pro-angiogenic function revealed that PSG1 did not bind to cells defective in glycosaminoglycan synthesis while it bound to their wild type counterparts (Lisboa et al. 2011). Binding of PSG1 to cell surface HSPG-expressing cells was competed with heparin, and the interaction of PSG1 with HS and heparin was further confirmed in solid-phase binding assays and affinity chromatography studies (Lisboa et al. 2011).

HSPG contribute to various biological processes, including cell growth, migration, and angiogenesis (Julian et al. 2001, Chiodelli et al. 2015). The HS moiety of HSPGs interacts with GFs, GF-binding proteins, proteases, chemokines, cytokines, and adhesive proteins (Fuster \& Wang 2010, Nagarajan et al. 2018). The interaction with HS regulates the stability of many ligand-receptor complexes functioning as a co-receptor, and it is implicated in the formation of GF gradients (Ruoslahti 1991, Yanagishita \& Hascall 1992, Fuster \& Wang 2010, Nagarajan et al. 2018).
PSG1 is comprised of four Ig-like domains designated as N, A1, A2, and B2, and different ligands interact with more than one domain of the protein (Shanley et al. 2013, Ballesteros et al. 2015, Rattila et al. 2019). Here, we found that only the B2 domain of PSG1 binds to HS, and the importance of this domain in the pro-angiogenic activity of this protein was confirmed in tube formation assays using EC and EVT cell lines, and in the aortic ring assay. The effect of PSG1 in the migration and metalloproteinase (MMP)-2 and -9 expression of ECs and EVT cell lines was also investigated. In addition, we determined that binding to HS and induction of endothelial tubulogenesis is not restricted to PSG1, as it is shared by other members of the human PSG family.

\section{Materials and methods \\ Cell lines}

The human endometrial endothelial cell (HEEC) line and the human trophoblast cell line Swan71 were provided by Dr Gil Mor (Wayne State University, Detroit, USA) and were cultured as previously described (Aldo et al. 2007, Straszewski-Chavez et al. 2009). The trophoblast cell line HTR8/SVneo was obtained from Dr Charles Graham (Queen's University, Ontario, Canada) (Graham et al. 1993). Porcine aortic ECs expressing the yellow fluorescent protein (PAE-YFP) were provided by Dr Enrique Zudaire (Janssen Pharmaceutical, Pennsylvania, USA) and were cultured in DMEM/F12 medium supplemented with $10 \%$ fetal bovine serum (FBS) and $100 \mathrm{U} / \mathrm{mL}$ penicillin/ streptomycin (PS) (Lisboa et al. 2011). Namalwa cells and Namalwa cells expressing syndecan-1 (Namalwa-SD1) or syndecan-2 (Namalwa-SD2) were provided by Dr Guido David (Department of Human Genetics, KU Leuven, Belgium) and were cultured in RPMI 1640 medium with 7.5\% FBS, PS, $2 \mathrm{mM}$ glutamine, and $0.5 \mathrm{mg} / \mathrm{mL}$ G418 (Zhang et al. 2001). Cells were maintained in a $37^{\circ} \mathrm{C}$ humidified incubator with $5 \% \mathrm{CO}_{2}$.

\section{Protein production}

PSG1-Fc, PSG1-His, PSG1N-FC, PSG1A1-FC, PSG1A2-FC, PSG1B2-FC, PSG9-FC, and a protein containing the $\mathrm{FC}_{\mathrm{C}}$ part of human IgG1 (designated as $\mathrm{Fc}$ ) were generated from the supernatant of stably transfected $\mathrm{CHO}-\mathrm{K} 1$ cells grown in a hollow fiber cartridge (FiberCell Systems, MD, USA) or by transient transfection of ExpiCHO cells as previously described (Ha et al. 2010, Ballesteros et al. 2015, Jones et al. 2016, Mendoza et al. 2020). The cDNAs encoding the PSGs with the $\mathrm{V} 5 \mathrm{His}$ tags were provided by $\mathrm{Dr}$ Tom Moore (University College Cork, Ireland) and the proteins were generated by transient transfection of Expi293 cells and purified with a HisTrap column followed by gel filtration chromatography as previously published (Warren et al. 2018). Plasmids encoding the cDNAs for the chimeric constructs between the A2 and B2 domains, PSG1 lacking the B2 (PSG1 $\triangle B 2$ ) domain, and the B2 domain of PSG6 (PSG6B2) were synthesized by Genscript, cloned into ECoRI-BgIII sites of the pFuse- 
IgG1 e3-Fc1 vector (InvivoGen, CA, USA), and the cDNA inserts were sequenced. $\mathrm{CHO}-\mathrm{K} 1$ cells were transfected with the plasmids encoding the chimeric constructs with Lipofectamine 2000 (Invitrogen) following the manufacturer's recommendations. The medium was replaced with OPTIMEM (Invitrogen) $6 \mathrm{~h}$ post-transfection and was harvested $72 \mathrm{~h}$ later. ExpiCHO cells (Thermo Fisher Scientific) were utilized to generate PSG6B2-FC and PSG1 $\triangle \mathrm{B} 2-\mathrm{FC}$ following the standard protocol and the supernatants were collected 6 days post-transfection. All Fc-tagged proteins were purified on protein A columns in an AKTA chromatography system (GE Healthcare) as previously described (Ballesteros et al. 2015, Rattila et al. 2019). Following elution from the column, proteins were buffer exchanged into PBS and concentrated with Amicon centrifugal filter units with a $10 \mathrm{kDa}$ cutoff membrane (Millipore). For quantitation, the purified proteins were separated on $4-12 \%$ NuPAGE Bis-Tris gels at different dilutions alongside known concentrations of BSA (Thermo Fisher Scientific) used as standards. The gels were stained with GelCode Blue (Thermo Fisher Scientific), and the proteins were quantitated by densitometry in a BioRad Gel Doc EZ Imager. The amino acid sequences of the proteins employed in our studies are shown as Supplementary material (see section on supplementary materials given at the end of this article) and the newly generated proteins for these studies are shown as Supplementary Fig. 1.

\section{Tube formation assay}

Tube formation assays were performed as previously described (Beltrame et al. 2018). Briefly, 96-well plates were coated with $50 \mu \mathrm{L} /$ well of Geltrex (Life Technologies) and incubated for 30 min at $37^{\circ} \mathrm{C}$ to allow for matrix solidification. Cell suspensions prepared in serum-free media (SFM) containing the indicated proteins or an equal volume of PBS were seeded (HTR8/SVneo and Swan71 cells at 15,000/well, PAE-YFP cells at 18,000/ well, and HEECs at 20,000/well) on top of the solidified Geltrex and incubated at $37^{\circ} \mathrm{C}$ with $5 \% \mathrm{CO}_{2}$. PBS and $\mathrm{FC}$ were used interchangeably as controls due to their similar effect in the assay. Images of tubules were captured using Olympus C-5060 digital camera connected to an inverted light microscope (10x, IMT2 Olympus) (at $6 \mathrm{~h}$ post-seeding for EVTs) or using a Leica AF600 DMI600B microscope with a built-in DFC365FX-566903911 camera (at $4 \mathrm{~h}$ and $12 \mathrm{~h}$ post-seeding for PAE-YFP and HEECs, respectively). Five wells were utilized for each treatment and five different fields per well were analyzed using the Wimtube image analysis software (Wimasis $\mathrm{GmbH}$, Spain) for ECs and the ImageJ software version $1.52 \mathrm{r}(\mathrm{NIH})$ for EVTs. To determine whether PSG1 binding to the cell surface was sufficient to induce tube formation, HEECs were incubated with PSG1-His or PBS for $1 \mathrm{~h}$. After washing with SFM, the cells were seeded on the matrix, as described previously. To define whether PSG1mediated tube formation in HEECs is dependent on MMPs, the cells were pre-treated with the pan-MMP inhibitor, GM6001 (cat\#BML-EI300, Enzo Life Sciences) or vehicle (DMSO) for $1 \mathrm{~h}$ before seeding on Geltrex and kept for the duration of the experiment.

\section{Determination of protein binding to cells by flow cytometric analysis}

Namalwa-SD1 or Namalwa-SD2 cells $\left(1 \times 10^{6}\right.$ cells/100 $\left.\mu \mathrm{L}\right)$ in fluorescence-activated cell sorting (FACS) buffer (PBS with $2 \% \mathrm{BSA}$ and $0.05 \% \mathrm{NaN} 3$ ) were kept on ice throughout the experiment and washed between incubation steps with FACS buffer. FCR blocking reagent (Miltenyi Biotec) was added to the cells for $30 \mathrm{~min}$ after which the cells were incubated with the indicated proteins for $1 \mathrm{~h}$. Binding of the Fc-tagged proteins was detected after $30 \mathrm{~min}$ incubation with Alexa Fluor 488-conjugated anti-human IgG1 Ab (cat\#A10631, Invitrogen). Binding of proteins containing the $\mathrm{V} 5 \mathrm{His}$ tags was detected with the anti-human PSG mAb (cat\#MAB6799, R\&D Systems), followed by allophycocyanin (APC) conjugated antimouse IgG (cat\#550826, BD Biosciences). The BD LSR II flow cytometer (BD Biosciences) was utilized for cell analysis and 50,000 events were collected per treatment with the FACS Diva software (BD Biosciences). The Flowlo software version 10.0.8 (BD Biosciences) was utilized for the analysis of the flow cytometric data.

\section{Surface plasmon resonance (SPR) studies}

The SPR experiments were performed in a BIAcore 3000 instrument (GE Healthcare) at $25^{\circ} \mathrm{C}$ with HBS-EP $(0.01 \mathrm{M}$ HEPES pH 7.4, $0.15 \mathrm{M} \mathrm{NaCl}, 3 \mathrm{mM}$ EDTA, and $0.005 \%$, $\mathrm{v} / \mathrm{v}$ Surfactant P20) as running buffer. Between 50 and 250 resonance units (RU) of biotinylated heparin (Cat\#375054, Millipore Sigma) were immobilized on a streptavidin-coated sensor chip (SA chip, cat\# BR100032; GE Healthcare). Before the immobilization to the sensor surface, the biotinylated heparin was pass through a PD SpinTrap G-25 desalting column (GE Healthcare). The chip surface was first washed three times with one-minute injections of $1 \mathrm{M} \mathrm{NaCl} / 50 \mathrm{mM}$ $\mathrm{NaOH}$. We next performed two 2 min injections of $5 \mu \mathrm{g} / \mathrm{mL}$ biotinylated heparin in HBS-EP buffer at a $5 \mu \mathrm{L} / \mathrm{min}$ flow rate. An empty surface was used as control. Proteins were diluted in HBS-EP buffer and injected at a flow rate of $30 \mu \mathrm{L} / \mathrm{min}$. The sensor SA surface with 200RU of immobilized heparin was used to test the binding of $1 \mu \mathrm{M}$ PSG1-Fc, PSG1A2-Fc, the chimeric proteins, and the protein comprising the Fc-tag. The chip surface was regenerated with a 1 min injection of $2 \mathrm{M}$ $\mathrm{MgCl}_{2}$ in $10 \mathrm{mM}$ Glycine $\mathrm{pH}$ 2.0. The real-time sensorgrams were aligned using the BIAevaluation 4.1 software (GE Healthcare).

\section{Gelatin zymography}

HTR8/SVneo, Swan71 cells, and HEECs were seeded at $1.2 \times 10^{6} / \mathrm{mL}$ in wells of a 24 -well plate in RPMI and DMEM supplemented with $10 \%$ FBS and endothelial growth media2 , respectively, and incubated until they reached $80-90 \%$ confluency. The cells were washed with PBS and the proteins in SFM were added for the indicated time. The media was then clarified by centrifugation and concentrated ten-fold in a Nanosep centrifugal device with a $10 \mathrm{kDa}$ molecular weight cut off membrane (Pall Corporation) prior to determination of protein concentration using the EZQ protein reagent 
(Invitrogen). One hundred micrograms from each sample were mixed 1:1 with Tris-Glycine SDS 2X Sample buffer (Life Technologies) and resolved in a 10\% Zymogram Plus (Gelatin) protein gel (Life Technologies). The gels were incubated three times for 30 min each with Zymogen Renaturing Buffer (Life Technologies) followed by addition of the Zymogen Developing Buffer (Life Technologies) for $30 \mathrm{~min}$ at RT. The gels were incubated with fresh developing buffer for $24 \mathrm{~h}$ at $37^{\circ} \mathrm{C}$, stained with GelCode Blue (Thermo Fisher Scientific) for $30 \mathrm{~min}$ and destained with water. Densitometry was performed using the ImageJ software version $1.52 \mathrm{r}(\mathrm{NIH})$.

\section{Wound healing assay}

HEECs in $2 \%$ FBS containing media were seeded at $1.3 \times 10^{5}$ cells in $300 \mu \mathrm{L} /$ well in a 48 -well plate. Swan71 at $1.2 \times 10^{5}$ cells/well and PAE-YFP at $1.3 \times 10^{5}$ cells/well were seeded in $300 \mu \mathrm{L}$ of $10 \%$ FBS containing media, respectively. Cells were incubated overnight to form confluent monolayers. The wells were washed with SFM after scratching with $200 \mu \mathrm{L}$ pipette tips. The indicated proteins were added in $0.2 \%$ FBS containing media for HEECs and in SFM for PAE-YFP and Swan71 cells. Cell migration was recorded by time-lapse microscopy (Leica AF6000 DMI6000B with a built in DFC365FX-566903900 camera) for 4, 6, and 12 h for PAE-YFP, Swan71, and HEECs, respectively. Images were captured every $20 \mathrm{~min}$ using the LASX software version 3.3.2 (Leica Microsystems). Images obtained from nine fields of three wells per treatment were analyzed with the 'Wound Healing ACAS Image Analysis' (MetaVi Labs Inc, Germany), and results are expressed as gap closure area (the measurement of the difference between gap area at $t=0 h$ and $t=12 h$ (for HEECs); $t=4 h$ (for PAE-YFP); $\mathrm{t}=6 \mathrm{~h}($ for Swan71).

\section{Proliferation assay}

HEECs were seeded on wells of a 96 -well plate at $2 \times 10^{4}$ cells/ well with endothelial basal medium- 2 medium with $0.2 \%$ FBS and treated in quadruplicate with PSG1-V5His or PBS. At 6 h or $24 \mathrm{~h}$ post-seeding, the cells were incubated with $20 \mu \mathrm{L}$ CellTiter 96 AQueous One Solution (Promega) and incubated for an additional $2 \mathrm{~h}$. The absorbance at $490 \mathrm{~nm}$ was recorded in a GloMax Discover instrument (Promega).

\section{Mice and aortic ring assay (ARA)}

Eight-week-old C57BL/6J mice (Jackson Laboratory) were housed in specific pathogen-free conditions on a $12 \mathrm{~h}$ light:12 $\mathrm{h}$ darkness cycle and fed a standard chow ad libitum. All animal experiments were performed in accordance with German Animal protection law. The ARA were performed as previously described (Baker et al. 2011). Briefly, mice were sacrificed by cervical dislocation, aortae were freed from perivascular fat tissue after thoracotomy and aortic ring segments $(1 \mathrm{~mm})$ were embedded in a collagen I gel (cat\#08-115, Millipore Sigma) containing the factors indicated in the figure legend. Aortic ring segments were cultured in Opti-MEM (Life Technologies) supplemented with GlutaMAX (Thermo Fisher Scientific) and incubated at $37^{\circ} \mathrm{C}$ in $5 \% \mathrm{CO}_{2}$. The medium was changed at day 3 of culture and sprouting was documented using a phasecontrast microscope (Leica ${ }^{\circledR}$ DFC 3000G, Leica Microsystems) at day 4. Maximum sprouting distance was analyzed using the ImageJ software version $1.52 \mathrm{r}$.

\section{Statistical analysis}

Each experiment was repeated at least three times with each repeat considered as a biological replicate, and the results of one representative experiment are shown. The numbers of technical replicates are indicated in the figure legends. Statistical data analysis was performed using the GraphPad Prism software version 7.05. Statistical significance was determined using the Mann-Whitney test when two groups were compared, or with the Kruskal-Wallis test followed by Dunn's multiple comparison tests for the comparison of three or more groups. When two-way ANOVA was applied, the residuals were tested with Shapiro-Wilks test for normality. A P-value of less than 0.05 was considered statistically significant.

\section{Results}

\section{Binding of PSG1 to HSPGs on the EC surface mediates tube formation}

We previously showed that PSG1 induces the formation of tubular structures by primary dermal human ECs and porcine aortic ECs (PAE) (Ha et al. 2010, Lisboa et al. 2011). In addition, we reported that PSG1 failed to induce endothelial tube formation by PAE cells pretreated with heparinase I and chondroitinase ABC (Ha et al. 2010, Lisboa et al. 2011). In order to better understand the involvement of glycosaminoglycans in PSG1-mediated tube formation, we performed additional studies to determine whether binding of PSG1 to HS on the EC surface is sufficient to elicit an increase in branching points (BP), tube number (TN), and tube length (TL). In addition, we studied the effect of PSG1 in a more relevant $\mathrm{EC}$ to decidual angiogenesis, HEECs. To this end, PSG1 or the control protein was added to the cells, followed by washes to remove the unbound protein prior to seeding the cells on the matrix (Fig. 1A). Figure $1 \mathrm{~B}$ shows that PSG1 induced more BPs, an increase in $\mathrm{TL}$ and in TNs than the Fc control protein.

\section{The B2 domain of PSG1 binds to HSPG and induces endothelial tube formation}

PSG1 does not bind to Namalwa cells, which lack HS expression, while it binds to Namalwa cells transfected with any of the four HSPG-containing syndecans (Alexopoulou et al. 2007, Lisboa et al. 2011). To define which domain(s) of PSG1 interact with $\mathrm{HS}$, we utilized Fc-tagged single-domain proteins ( $N, A 1, A 2$ and B2), and also generated a protein comprised of the $N, A 1, A 2$ domains of PSG1 but lacking the B2 domain, designated as PSG1 $\triangle$ B2-FC (Supplementary Fig. 1). We tested 
A

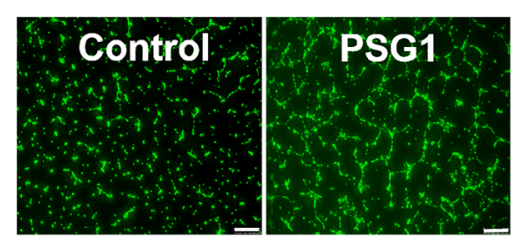

B

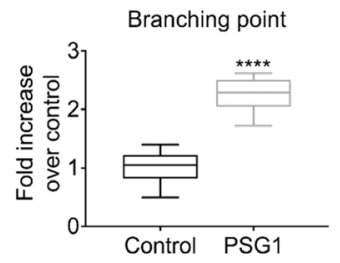

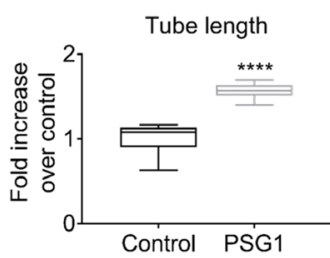

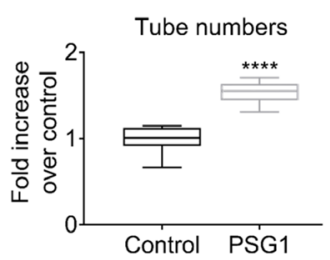

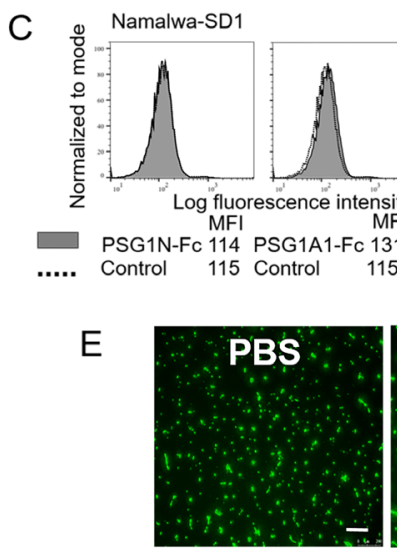

F

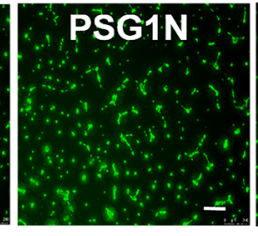

Branching point

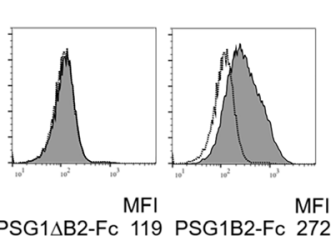

D
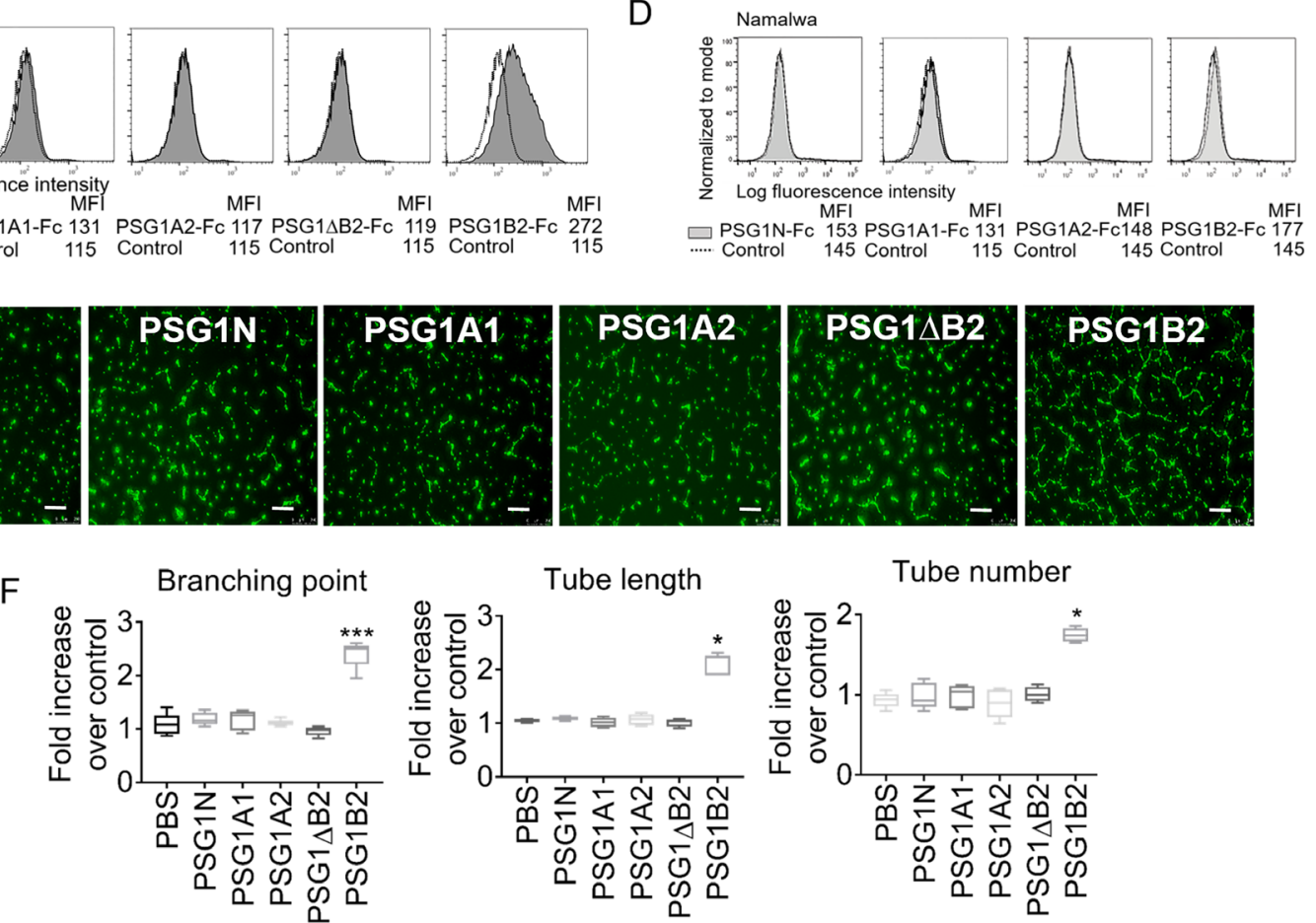
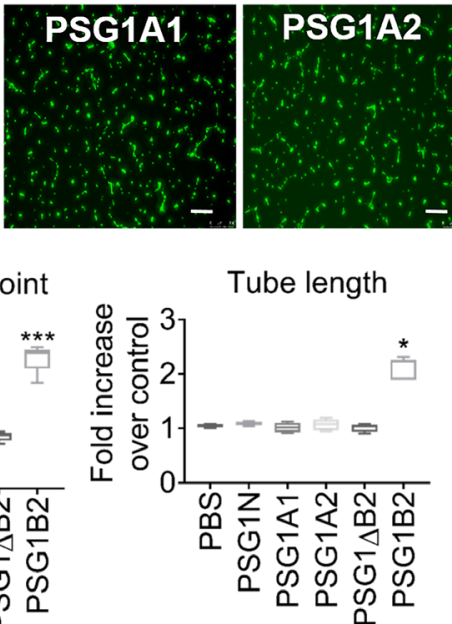
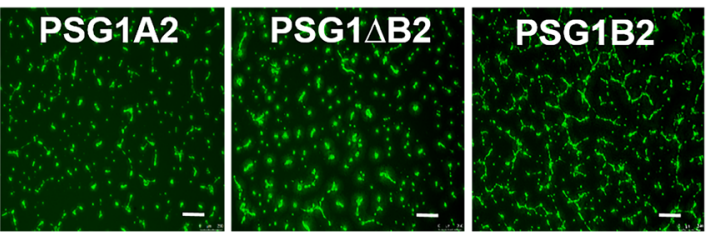

Tube number

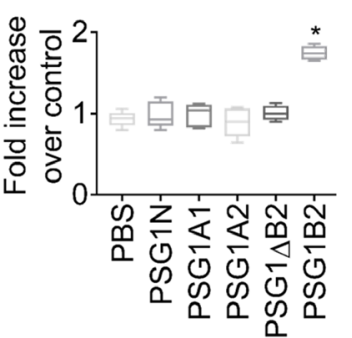

Figure 1 Binding of PSG1 to heparan sulfate proteoglycans (HSPGs) on the cell surface is sufficient for PSG1-mediated endothelial tube formation and identification of the domain of PSG1 required for HS binding and pro-angiogenic activity of this protein. (A) HEECs were incubated with $1500 \mathrm{nM}$ PSG1-His or a protein containing the Fc-tag as control for $1 \mathrm{~h}$ on ice. After washing, cells were seeded on the gelled growth factor reduced Geltrex (GFR-Geltrex). Representative images of the endothelial tube structures formed with PSG1 or control protein are shown. (B) Image analyses of tube structures formed are expressed as branching point, tube length, and tube numbers. (C and D) Namalwa cells stably transfected with syndecans-1 (Namalwa-SD1) (C) and Namalwa cells (D) were treated with PSG1N-FC, PSG1A1-FC, PSG1A2-FC, and a protein consisting of an FC-tag (control) at $10 \mu \mathrm{g} / \mathrm{mL}$, PSG1 $\triangle \mathrm{B} 2-\mathrm{FC}$ at $20 \mu \mathrm{g} / \mathrm{mL}$, and PSG1B2-FC at $5 \mu \mathrm{g} / \mathrm{mL}$, followed by Alexa Fluor 488-conjugated anti-human Fc Ab. The median fluorescence intensity (MFI) of each treatment is indicated. (E) HEECs were seeded on the gelled GFR-Geltrex and treated with the indicated proteins at $1000 \mathrm{nM}$ or with equal volume of PBS (control); representative images of the endothelial tube structures formed in response to the treatments are shown. (F) Image analyses of the tube structures shown in E. The average of the replicate wells with the cells incubated with Fc control (in B) or with PBS (in F) is considered as 1. Magnification =5x; Scale bar $=250 \mu \mathrm{m}$. Quantitative results are expressed as the median, interquartile range, and minimum and maximum values of replicates $(n=9$ for $\mathrm{B}$ and $n=5$ for $\mathrm{F})$; one representative of three individual experiments is shown. Statistical significance was obtained by Mann-Whitney test (in B) or by Kruskal-Wallis test, followed by Dunn's multiple comparison tests (in F). $\left({ }^{* * * *} P<0.0001,{ }^{* * *} P<0.0002\right.$, and $* P<0.03$ ).

whether these proteins bind to syndecan-1-expressing Namalwa cells (Namalwa-SD1) by flow cytometry and found that only the protein comprised of the B2 domain bound to Namalwa-SD1 cells over the control (Fig. 1C). In agreement with this data, PSG1 $\Delta \mathrm{B} 2-\mathrm{FC}$ did not bind to the Namalwa-SD1 cells (Fig. 1C) and as expected, none of these proteins bound to WT Namalwa cells (Fig. 1D).

We next tested which domain(s) of PSG1 induces tube formation by HEECs. As shown in Fig. 1E and F, tube structures were only formed over the observed in the control-treated cells in the presence of the protein consisting of the $\mathrm{B} 2$ domain. The $\mathrm{N}, \mathrm{A} 1, \mathrm{~A} 2$ single domain proteins, and PSG1 $\triangle \mathrm{B} 2$ did not induce tube formation by the HEECs (Fig. 1E and F). Similar results were obtained with PAE-YFP cells (Fig 2A and B). We also examined whether the B2 domain was required for endothelial tube formation when the proteins were mixed with Geltrex and found that PSG1 induced tube formation over the control when mixed with the matrix while PSG1 $\Delta$ B2 did not (Fig 2C and D). 
A
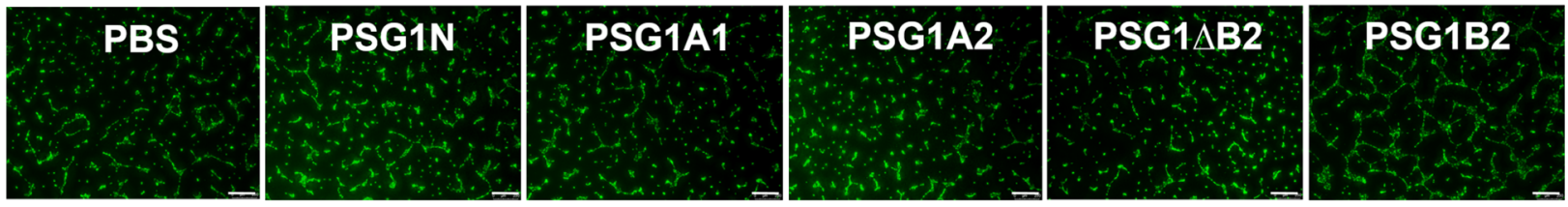

B
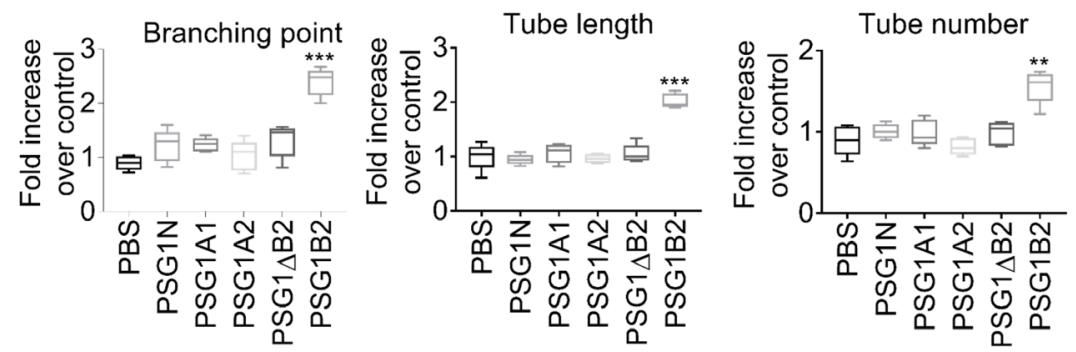

C

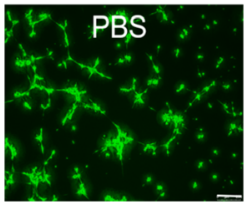

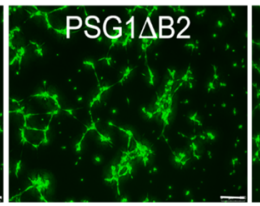

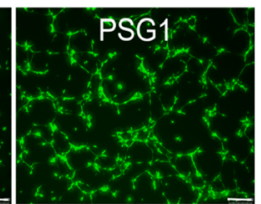

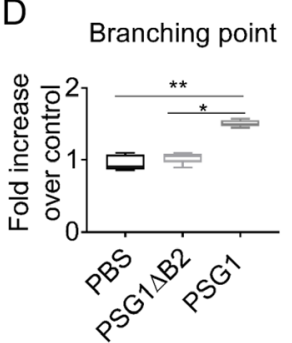
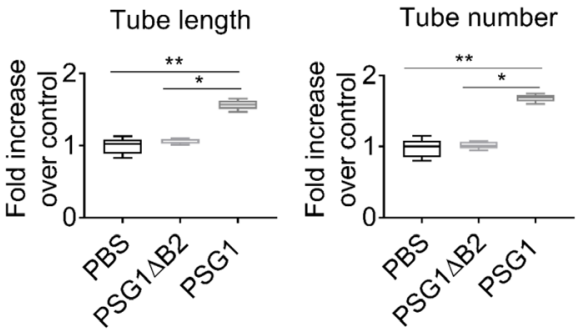

Figure 2 The B2 domain of PSG1 is required for endothelial tube formation when either added in media or mixed with GFR-Geltrex. (A) Representative images of the tube structures formed by PAE-YFP in response to various domains of PSG1 added at $1000 \mathrm{nM}$ or equal volume of PBS (control) in the media are shown. (B) Quantitative analysis of tube structures formed with PAE-YFP in response to various treatments applied in A are shown as described in Fig 1B. (C) Representative images of the tube structures formed by HEECs seeded on the gelled GFR-Geltrex premixed with the indicated proteins at $1000 \mathrm{nM}$ or with equal volume of PBS (control). Magnification $=5 \mathrm{x}$; Scale bar $=250 \mu \mathrm{m}$ (for A and C). (D) Quantitative analysis of tube structures formed by HEECs in response to the treatment applied in C are shown as described in Fig. 1B. The average of the replicate wells with PBS added in Geltrex or to media is considered as 1 . Results are expressed as the median, interquartile range, and minimum and maximum values of replicates $(n=5)$; one representative of three independent experiments is shown. Statistical significance was obtained by Kruskal-Wallis test, followed by Dunn's multiple comparison tests. ${ }^{* * *} P<0.0002, * * P<0.002$, and $\left.{ }^{*} P<0.03\right)$.

\section{Amino acids 43-59 in the B2 domain of PSG1 interact with HSPGs and heparin}

To identify the region in the B2 domain that interacts with HSPGs, we generated chimeric proteins composed of parts of the A2 domain, which lacks the ability to interact with HS, and parts of the B2 domain. The chimeric constructs were designed based on a model of the B2 domain to replace entire $\beta$-sheets and loop structures indicated by different colors in Fig. 3A. The amino acid sequences of the resulting chimeric proteins are shown in Fig. $3 \mathrm{~B}$ and were designated as A2/B2 (1-20), A2/B2 (21-42), A2/B2 (43-59), and A2/ B2 (60-84) (Supplementary Fig. 1). These proteins were tested for binding to heparin by SPR. We observed that the A2/B2 (43-59) bound considerably better to heparin when compared to the other chimeras and the control protein (Fig. 3C). In addition, we analyzed the binding of the chimeric proteins to Namalwa-SD1 cells by flow cytometry (Fig. 3D). Among the four chimeras, A2/B2 (43-59) and A2/B2 (1-20) bound to Namalwa-SD1 over the control protein, with the A2/B2 (43-59) showing the highest binding activity. As expected, none of the chimeras bound to the untransfected Namalwa cells (data not shown). These experiments strongly suggest that the 43-59 region of the B2 domain is required for the interaction of this domain with HS.

\section{Positively charged amino acids in the 43-59 region of the B2 domain of PSG1 are required for binding to HSPGs and the induction of endothelial tubulogenesis}

The negative charges of the HS chains are believed to interact with positively charged patches of proteins often delineated by clusters of arginine, lysine, and histidine (Meneghetti et al. 2015, Smock \& Meijers 2018). Therefore, we hypothesized that mutation of these amino acids in the 43-59 region of the B2 would abolish the interaction with HSPGs (Fig. 3E). To test this hypothesis, we generated a mutant of the A2/B2(43-59) where $\mathrm{K} 48, \mathrm{R} 52, \mathrm{H} 53, \mathrm{~K} 57$, and $\mathrm{H} 58$, which correspond to the B2 domain, were replaced by glutamic acid and designated this mutant as A2/B2(43-59) $\mathrm{E}_{\text {mut }}$ (Fig. 3E and Supplementary Fig. 1). We observed that A2/B2(43-59) 
A

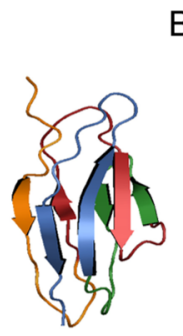

B

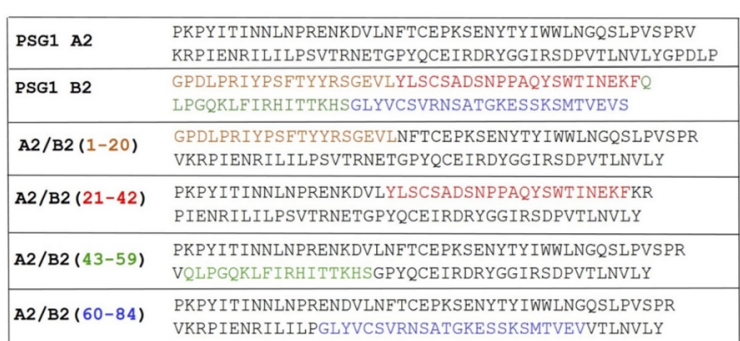

D

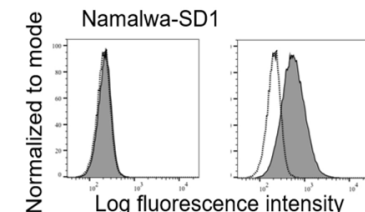

$\mathrm{MFI}$

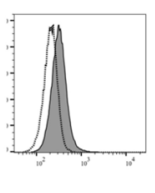

$\mathrm{MFI}$

MFI

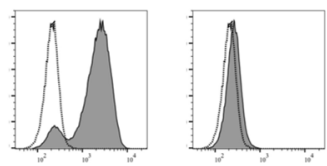

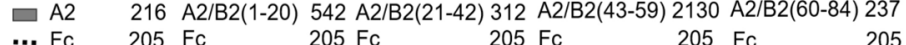

E

\begin{tabular}{|ll|}
\hline A2/B2 (43-59) & PKPYITINNLNPRENKDVLNFTCEPKSENYTYIWWLNGQSLPVSP \\
& RVQLPGQKLFIRHITTKHSGPYQCEIRDRYGGIRSDPVTLNVLY \\
\hline A2/B2 (43-59) E & PKPYITINNLNPRENKDVLNFTCEPKSENYTYIWWLNGQSLPVSPR \\
& VQLPGQELEIEEITTEESGPYQCEIRDRYGGIRSDPVTLNVLY \\
\hline
\end{tabular}

$\mathrm{F}$
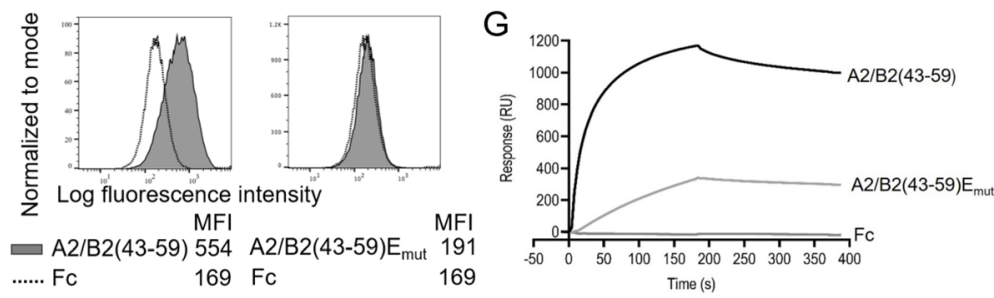

C

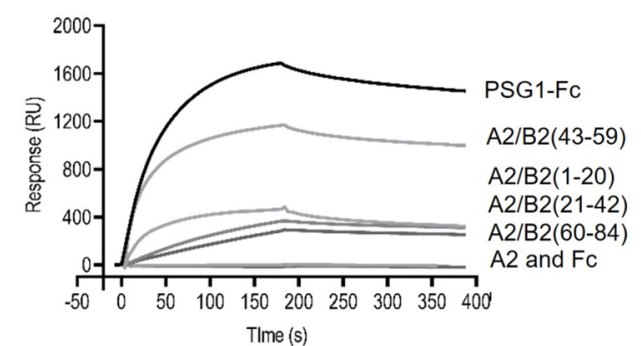

$\mathrm{H}$

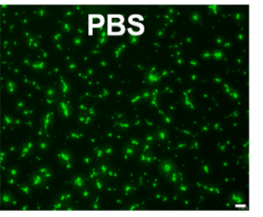

A2/B2 (43-59)
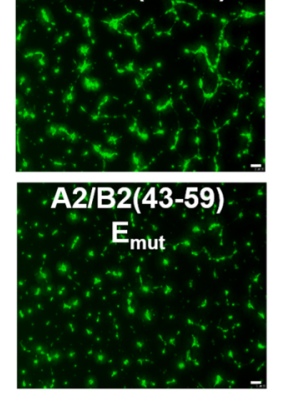
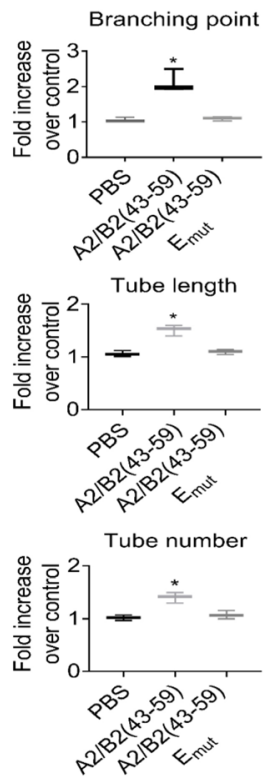

Figure 3 Amino acids 43-59 in the B2 domain of PSG1 interact with HSPGs and heparin, and the positively charged amino acids in that region of the B2 domain are required for HSPG-binding and for endothelial tube formation. (A) A predicted model of the B2 domain of PSG1 with the theoretical demarcation of the four regions is shown in different colors. (B) Amino acid sequences of the A2 and B2 domains of PSG1 and the chimeric proteins. (C) SPR sensorgram of the interaction of the indicated proteins with heparin. All the proteins were injected at $1 \mu \mathrm{M}$ in HBS-EP buffer over a sensor surface with immobilized heparin during a $3 \mathrm{~min}$ association and 3 min dissociation phase. A protein consisting of an Fc-tag was used as control. (D) Namalwa-SD1 cells were treated with the indicated proteins, followed by Alexa Fluor 488-conjugated antihuman Fc Ab. (E) Amino acid sequences of the A2/B2(43-59) and its mutant with glutamic acid replacing the K48, R52, H53, K57, and H58 in the 43-59 region, designated as A2/B2(43-59) $\mathrm{E}_{\text {mut }}$ (F) Namalwa-SD2 cells were incubated with the indicated proteins at $10 \mu \mathrm{g} / \mathrm{mL}$, followed by Alexa Fluor 488-conjugated anti-human Fc Ab. (G) A2/B2(43-59) and A2/B2(43-59) $\mathrm{E}_{\text {mut }}$ were injected at $1 \mu \mathrm{M}$ in HBS-EP buffer over a heparin surface as described in part C. (H) PAE-YFP cells were seeded on the gelled GFR-Geltrex and treated with the indicated proteins at $1000 \mathrm{nM}$ or equal volume of PBS (control). Representative images of the endothelial tube structures formed are shown. Magnification $=5 x$; Scale bar $=250$ $\mu \mathrm{m}$. (I) Image analyses of the tube structures are expressed as described in Fig. 1B. The average of replicate wells with the cells treated with PBS is considered as 1. Quantitative results are expressed as the median, interquartile range, and minimum and maximum values of replicates $(n=3)$; one representative of three individual experiments is shown. Statistical significance was obtained by Kruskal-Wallis test, followed by Dunn's multiple comparison tests $(* P<0.03)$.

$E_{\text {mut }}$ did not bind to syndecan-expressing Namalwa cells (Fig. 3F) and that it bound considerably less than the A2/B2(43-59) to heparin (Fig. 3G). We next tested the ability of A2/B2(43-59) and A2/B2(43-59) $\mathrm{E}_{\text {mut }}$ to induce endothelial tube formation. As shown in Fig. $3 \mathrm{H}$ and $\mathrm{I}$, PAE-YFP cells formed tube networks in the presence of A2/B2(43-59) but not when incubated with A2/B2(43$59) \mathrm{E}_{\mathrm{mut}}$. Altogether, the results indicate that the positively charged amino acids in the 43-59 region of B2 domain are involved in the binding to $\mathrm{HS}$ and are required for the induction of endothelial tube formation.

\section{PSG1 induces endothelial-like tube formation by EVT cell lines}

During remodeling of the uterine spiral arteries, EVTs adopt an EC-like phenotype and replace the EC lining (Ashton et al. 2005). Therefore, we tested whether PSG1 could induce endothelial-like tube formation by two EVT cell lines, HTR8/SVneo and Swan71. The cells were incubated with PSG1 at 15, 30 and $60 \mu \mathrm{g} /$ $\mathrm{mL}$, and PSG1 induced tube formation by HTR8/SVneo and Swan71 cells over the control protein starting at 
$30 \mu \mathrm{g} / \mathrm{mL}$ (500 nM) (Fig. 4A and B, and data not shown). In accordance with our observations in ECs, the B2 domain was required for the PSG1-mediated tube formation by EVTs, as the cells treated with PSG1 $\triangle \mathrm{B} 2-\mathrm{FC}$ at all three concentrations tested did not form tubes when compared to the control (data not shown).

\section{Effect of PSG1 in cell migration and matrix metalloproteinase (MMP)-2 and -9 expression}

The process of angiogenesis involves cell migration, proliferation, and remodeling of extracellular matrix (ECM) through proteases (Conway et al. 2001, Fuster \& Wang 2010). Hence, we investigated whether PSG1 plays a role in any of these processes. Because the expression of MMP-2 and MMP-9 by EVTs is important for their ECM-remodeling function, we examined whether PSG1 modulates the expression of these enzymes (Isaka et al. 2003, Chen \& Khalil 2017). As shown in Fig. 4C and D, PSG1 induced higher expression of MMP-2 by HTR8/ SVneo and Swan71 cells (data not shown) while the expression of MMP-9 remained unchanged. Interestingly, we did not observe an effect of PSG1 on MMP-2 and MMP-9 expression by HEECs (data not shown). We next performed wound healing assays with HEECs and analyzed the migration of the cells incubated with PSG1 or PBS added to the media. Cells incubated with PSG1 covered an area within the gap that was larger than the area covered by the cells in the presence of PBS (Fig. $5 \mathrm{~A}$ and B). Similar results were obtained with PAE-YFP cells (data not shown). The PSG1 migration-enhancing effect was not due to changes in cell proliferation as cells did not proliferate differentially in the presence or absence of PSG1 (Fig. 5C). On the other hand, we did not observe differences in migration of the EVT cell lines as compared to the control-treated cells when PSG1 was added to the media (data not shown). Overall, these results indicate that PSG1 differentially regulated the MMP secretion and migratory activity of ECs and EVT cell lines.

\section{Binding of other members of the human PSG family to HSPGs}

We explored whether other human PSGs can bind to $\mathrm{HS}$ to determine if this is a conserved function of these glycoproteins. The B2 domains of human PSGs share $72-95 \%$ amino acid sequence identity (Fig. 6A), and two family members (PSG9 and PSG6) have a potential $\mathrm{N}$-linked glycosylation site that could interfere with $\mathrm{HS}$ binding. We tested binding of PSG2, PSG4, PSG5, PSG7, PSG8, PSG9 and PSG11 to Namalwa-SD1 cells and found that all bound to these syndecan-expressing cells (Fig. 6B). Unfortunately, we could not test PSG3 due to insufficient amount of protein resulting from low yield (Warren et al. 2018). We selected PSG9 to test whether, like PSG1, they induced endothelial tube formation. As shown in Fig. 6C, PSG9 induced tube formation. In addition, we determined that the B2 domain of PSG6 is sufficient to bind to $\mathrm{HS}$ and to elicit tube formation (Fig. 6B, D and Supplementary Fig. 1).
A
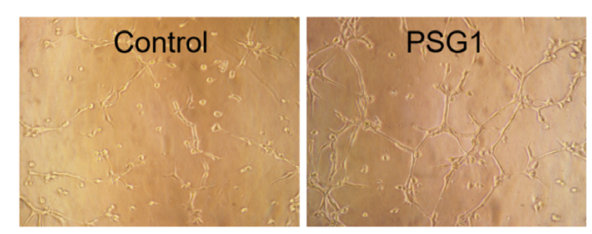

C

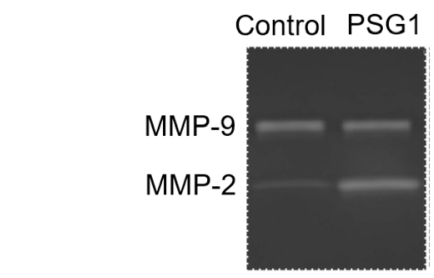

B

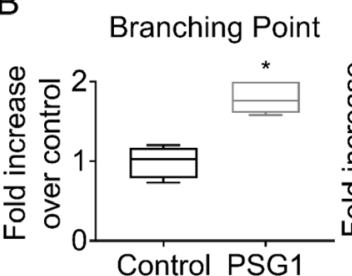

D
Tube length

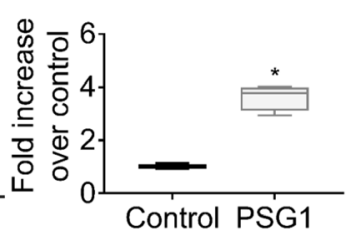

Tube number

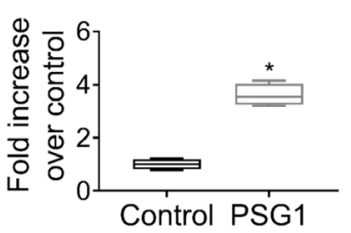

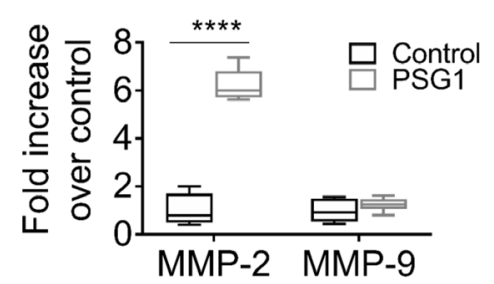

Figure 4 PSG1 induces endothelial-like tube formation and an increased expression of MMP-2 by HTR/SVneo cells. (A) Representative images of the tube structures formed by HTR/SVneo cells seeded on the gelled GFR-Geltrex and treated with PSG1-His at $500 \mathrm{nM}$ or equal volume of PBS (control). Magnification=10x. (B) Quantitative analyses of the tube structures formed by HTR/SVneo cells are expressed as described in Fig. 1B. (C and D) An image of a representative gelatin zymograph and the related quantification of MMP-2 and MMP-9 secretion by HTR8/SVneo in response to PSG1-treatment. The average of the replicate wells with the cells seeded in the presence of PBS is considered as 1 in panels B and D. Quantitative results are expressed as the median, interquartile range, and minimum and maximum values of replicates $(n=6$ for B and $n=4$ for D); one representative of three individual experiments is shown. Statistical significance was obtained by Mann-Whitney test in B. For D, data was analyzed using two-way ANOVA followed by Sidak's multiple comparison test and residuals were tested with Shapiro-Wilk's test for normality. $\left.{ }^{* * * *} P<0.0001, * P<0.03\right)$. 
A

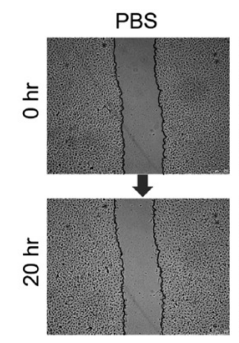

B

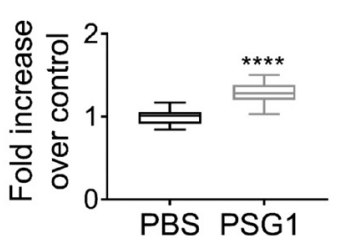

PSG1

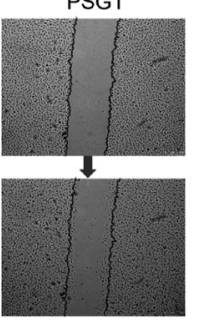

C

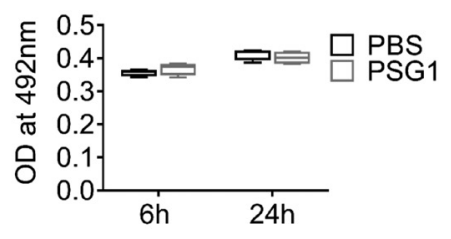

Figure 5 PSG1 enhances migration of HEECs without affecting their proliferation. (A) Confluent monolayers of HEECs were treated with PSG1-V5His or PBS (control) added in the media post-scratching (0 h). Cell migration was recorded periodically for $12 \mathrm{~h}$ and representative images are shown with the black lines indicating where the cell fronts were at $0 \mathrm{~h}$. (B) Quantitative analyses of wound healing assays performed with HEECs in the presence of PSG1-V5His or PBS (as control). The average of replicate wells with the cells treated with PBS is considered as 1. Gap covered area were calculated as described in the 'Materials and methods' section. (C). HEECs were seeded in the presence of PSG1-V5His, PSG1 $\triangle$ B2-FC, or PBS (as control) in $0.2 \%$ serum-containing media. Cell proliferation was analyzed at $6 \mathrm{~h}$ and $24 \mathrm{~h}$ as described in the 'Materials and methods' section. Quantitative results are expressed as the median, interquartile range, and minimum and maximum values of replicates ( $n=9$ for B, $n=4$ for $C$ ); one representative of three individual experiments is shown. Statistical significance was obtained by Mann-Whitney test $(* * * * P<0.0001$ ) (in B) or by two-way ANOVA followed by Sidak's multiple comparison test and the residuals were tested with Shapiro-Wilk's test for normality (in C).

\section{The B2 domain is required for the PSG1-mediated pro-angiogenic effect in the $A R A$}

We performed experiments to determine whether PSG1 has pro-angiogenic activity in an assay in which nonECs are also present (Baker et al. 2011). To this end, aortic rings were seeded on collagen I containing PSG1, PSG1 $\triangle B 2-F C$, or equal volumes of PBS as control. As shown in Fig. 6E, 4 days post-treatment, PSG1 showed higher maximum capillary sprouting distance when compared to the control-treated rings. In addition, we observed no significant difference in capillary sprouting distance from the rings treated with PSG1 $\triangle \mathrm{B} 2$ and the control. These results indicate that the PSG1-mediated angiogenic activity in this assay is also dependent on the B2 domain of the protein.

\section{Discussion}

Extensive decidual vascular modifications occur prior to placental spiral arterial remodeling, establishing the

conditions for successful implantation and early fetal development (Sherer \& Abulafia 2001, Lima et al. 2014). As pregnancy progresses, invasion of decidual vessels by endovascular EVTs starts at approximately 8 weeks after the earlier plugging of the vessels (Pijnenborg et al. 1980). In this report we extended our prior investigations to explore the potential activity of PSG1 in decidual angiogenesis using HEEC and confirmed that PSG1 binding to HSPG on the cell membrane rather than the matrix is required for this activity. Cell-surface HSPGs include SD1-4, which have all been implicated in EC biology, and GPI-tethered glypicans, CD44, and betaglycan (Sarrazin et al. 2011, Teng et al. 2012, De Rossi \& Whiteford 2014). SD2 and SD4 are expressed in HEECs and expression SD1-4 was detected in PAEYFP cells (data not shown). We showed that PSG1 induces tube formation in a B2-dependent manner even when mixed with Geltrex indicating that PSG1 remains in a dynamic equilibrium between the matrix, which contains HSPGs, and the membrane of the cells.

The B2 is the only domain of PSG1 that bound to HS and induced tube formation. This domain also binds to the LAP of TGF- $\beta 1$ and to integrin $\alpha 5 \beta 1$, although which amino acids are involved in these interactions remains unknown (Ballesteros et al. 2015, Rattila et al. 2019). We showed that a region between amino acids 43-59 of the B2 domain are involved in the interaction with HS. Basic amino acids are key contributors in the interaction of proteins with $\mathrm{HS}$, therefore it is not surprising that mutations of K48, R52, H53, K57, and H58 reduced the interaction with HS as demonstrated in the SPR and flow cytometric analysis (Esko \& Linhardt 2009, Rudd et al. 2017). We also observed binding of the protein that included amino acids $1-20$ of the B2 domain to SD-expressing cells over the control protein. Therefore, the possible participation of these amino acids in HS-binding cannot be ruled out.

The acquisition of the endovascular phenotype by first-trimester EVTs is crucial for spiral artery remodeling (Zhou et al. 1997a,b, Pijnenborg et al. 2006). EVT cell lines are known to spontaneously form tubules when plated on Matrigel and to form extensive networks in response to pro-angiogenic factors (Lala et al. 2012, Wang et al. 2018). Tubulogenesis assays using the HTR-8/ SVneo and Swan71 cell lines to model the acquisition of endovascular phenotype by EVTs have been widely employed and are considered a good alternative to the difficulties of studying angiogenesis using primary EVTs (Graham et al. 1993, Basak \& Duttaroy 2013, Renaud et al. 2014, Beltrame et al. 2018, Reppetti et al. 2020). Because PSG1 bound to HTR8/SVneo and Swan71 in a HS-dependent manner (data not shown), we hypothesized that PSG1 might induce tube formation by these cells. We found that PSG1 but not PSG1 lacking the B2 domain induced tube formation in these two EVT cell lines. We previously showed that PSG1 induces VEGF-A secretion by monocytes and EVT cell lines in a 
A

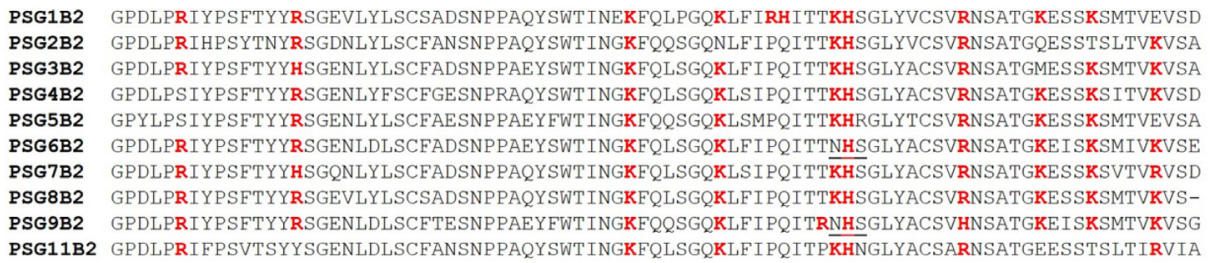

B

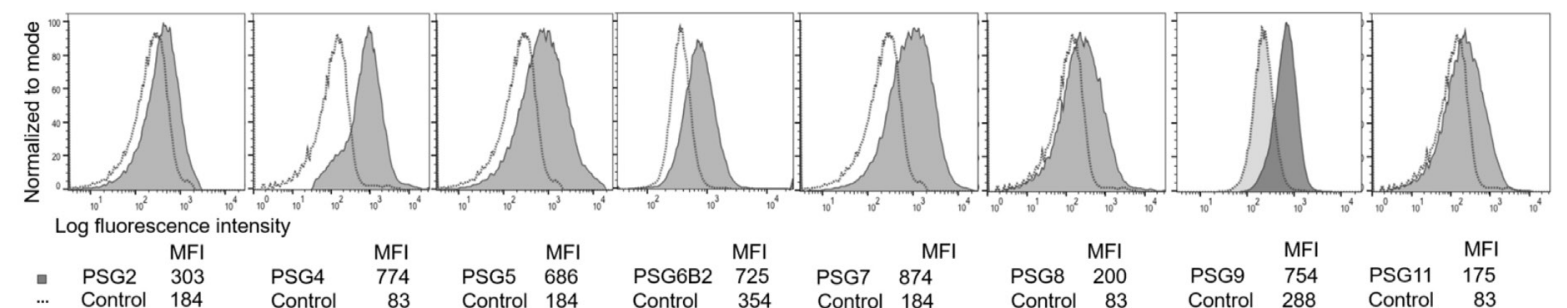

C
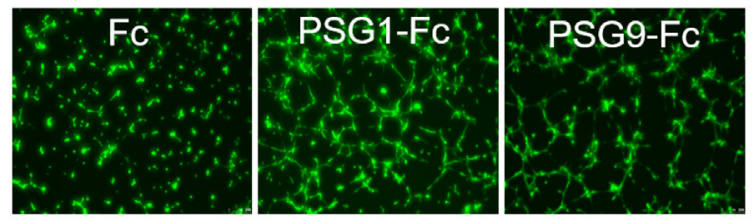

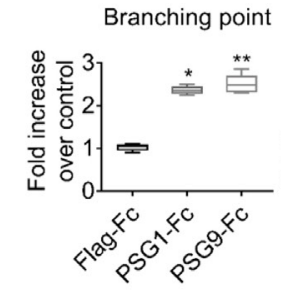

Branching point
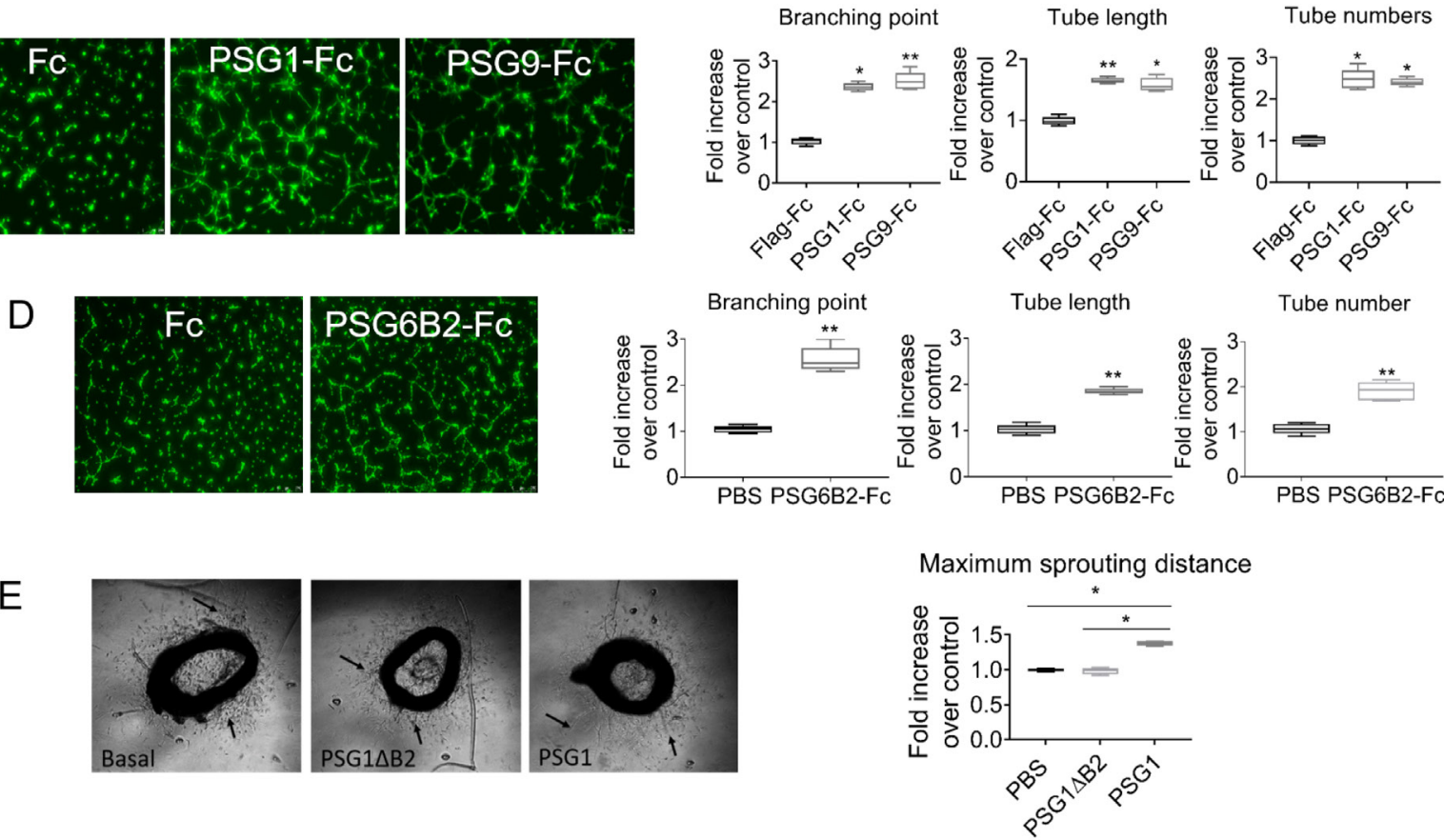

Figure 6 All human PSGs bind to HSPGs and PSG1 induces capillary sprouting in mouse aortic rings in a B2 domain-dependent manner. (A) The positively charged amino acids in the B2 domains of all human PSGs are shown in red and the potential glycosylation sites in the B2 domains of PSG6 and PSG9 are underlined. (B) Namalwa-SD1 cells were treated with PSG2-V5His $(50 \mu \mathrm{g} / \mathrm{mL})$, PSG4-V5His $(30 \mu \mathrm{g} / \mathrm{mL})$, PSG5-V5His $(80$ $\mu \mathrm{g} / \mathrm{mL})$, PSG6B2-Fc $(5 \mu \mathrm{g} / \mathrm{mL})$, PSG7-V5His $(50 \mu \mathrm{g} / \mathrm{mL})$, PSG8-V5His $(50 \mu \mathrm{g} / \mathrm{mL})$, PSG9-Fc $(20 \mu \mathrm{g} / \mathrm{mL})$, PSG11-V5His (50 $\mu \mathrm{g} / \mathrm{mL})$, and a protein consisting of the $\mathrm{FC} \operatorname{tag}(5$ and $20 \mu \mathrm{g} / \mathrm{mL}$ ) used as control. Binding of the proteins containing the V5His tags was detected with the anti-PSG MAb6799 followed by APC-conjugated anti-mouse IgG (anti-mlgG-APC) and cells incubated only with the primary and secondary Abs without the addition of PSGs were included as control. Binding of the Fc-tagged proteins was detected with an Alexa Fluor 488-conjugated anti-human Fc Ab. The median fluorescence intensity (MFI) of each treatment is shown. (C and D) PAE-YFP cells were seeded on the gelled GFR-Geltrex in the presence of the indicated proteins. Quantitative analyses of the tube structures are expressed as described in Fig. 1B. Results are shown as the median, interquartile range, and minimum and maximum values of replicates $(n=5)$; one representative of three individual experiments is shown. (E) Micrographs showing capillary sprouting of mouse aortic rings in the presence of PSG1, PSG1 $\triangle B 2$, or PBS (control), 4 days posttreatment. Arrows show the tips of capillary sprouts, indicating length of capillary sprouts in the presence of respective treatments. Quantitative analyses of maximum sprouting distance (average of $n \geq 15$ wells per mouse and $n=4$ mice per experiment) are expressed after normalization to control. Statistical significance was obtained by Kruskal-Wallis test followed by Dunn's multiple comparison tests (in C and E) or by MannWhitney test (in D) $(* * P<0.002, * P<0.03)$.

TGFB dependent manner (Ha et al. 2010). Therefore, we propose that secretion of PSGs by EVTs may function in an autocrine manner to enhance the angiogenic activity of these cells by two different mechanisms. In addition, we propose that PSGs, secreted by trophoblasts as early as 3-4 days post-fertilization, could bind to ECs in the decidua and promote angiogenesis (Dimitriadou et al. 1992, Aronow et al. 2001). 
When added to the media, PSG1 increased the migration of ECs while having no effect on the migration of Swan71. However, we have previously shown that when coated on a well, PSG1 increased the migration of primary and EVT cell lines, indicating that soluble and immobilized PSG1 may affect the migration of these cells by different mechanisms (Rattila et al. 2019). The up-regulation of MMP-2 and MMP-9 has been correlated with the pro-angiogenic activity of several molecules, including IL-8, and with the invasive capacity of EVTs (Li et al. 2003, Peng et al. 2016). PSG1 increased MMP-2 secretion by EVTs while it did not increase MMP-2 secretion by ECs. While we did not observe an effect of PSG1 in the secretion of MMP-2/9 in HEECs, we noted a reduction in the PSG1-mediated tube formation in the presence of a pan-MMP inhibitor (data not shown). Therefore, it is possible that PSG1 regulates MMPs other than MMP-2 and -9 in ECs.

The B2 domains of human PSGs differ both in number and position of positively charged residues. Nevertheless, we found that the HS-binding ability is conserved among all the nine PSGs tested. In the analysis of the HS interaction with human PSGs, we utilized an $\mathrm{Ab}$ that binds to an epitope present in the A1 and A2 domain (Warren et al. 2018). The lack of complete conservation of the epitope and the absence of one of the two recognized domains in some PSGs may explain that different concentrations were required to observe binding to the SD-transfectants. We found that PSG6 and PSG9, which have fewer positively charged amino acids in the B2 domain than PSG1, induced tube formation. Polar residues, such as glutamine, nearby positively charged amino acids or hydrophobic residues, for example, tyrosine, have been found to contribute to HS-binding and may contribute to the ability of some PSGs to bind HS (Hascall \& Esko 2015, Sarkar \& Desai 2015). Murine PSG17, 22, and 23 were shown to bind to HS through their N1 domain, and PSG22 and PSG23 induced endothelial tubulogenesis highlighting the conservation of this function of PSGs in different species although different domains of the proteins appear to be required for the same function (Sulkowski et al. 2011, Blois et al. 2012).

The PSG1-mediated angiogenic activity in the ex vivo ARA was also dependent on the B2 domain of PSG1 even when a different ECM was utilized for these experiments. Cultivation of the entire vascular wall in the ARA enables to investigate not only the role of ECs in new vessel formation but also the impact of smooth muscle cells, pericytes of the vasa vasorum, progenitor cells of the aortic adventitia as well as local inflammatory cells such as macrophages (Baker et al. 2011, Worsdorfer et al. 2017). Furthermore, the ARA evaluates the important initiation step of activating the ECs in the vessels and their sprouting for creating new capillaries (Nakatsu et al. 2003, Nowak-Sliwinska et al. 2018).
How binding to HS by PSGs is sufficient to induce tube formation and sprouting in aortic rings is puzzling. Since HSPGs serve mostly as co-receptors, PSGs may engage a low-affinity receptor, which requires HS. Another possibility is that PSGs might be involved in the competitive binding of HSPGs and displace a bound molecule, undefined in our current study, for promoting angiogenesis as observed in the competitive glycosaminoglycan binding for chemokine cooperativity (Verkaar et al. 2014). Surprisingly, we found that PSG1 without the B2 domain increased EC sprouting over the control in the ARA when the experiment was performed in the presence of $2.5 \%$ or higher FBS concentrations. Similarly, we observed that in the presence of serum, PSG1 lacking the B2 domain induced tube formation by PAE-YFP on collagen I over the control, although the pro-angiogenic effect of this protein was significantly lower when compared to that of full-length PSG1. These studies suggest that either serum may up-regulate an unknown binding partner on the cell surface, which is absent under serum-free conditions and independent of the B2 domain, or a serum component indirectly serves as an adaptor protein for cellular binding.

In summary, we observed that PSG1 is proangiogenic in ECs and EVTs cell lines. Also, the B2 domain of PSG1 is important for this activity and exerts this function through an interaction with HSPGs. Since all human PSGs tested bind to HSPGs, the pro-angiogenic activity might be a conserved function of human PSGs.

\section{Supplementary materials}

This is linked to the online version of the paper at https://doi. org/10.1530/REP-20-0169.

\section{Declaration of interest}

The authors report no financial or other conflict of interest relevant to this study. The fundders had no role in the design of the study; in the collection, analyses, or interpretation of data; in the writing of the manuscript, or in the decision to publish the results.

\section{Funding}

The research was supported by a grant from the Collaborative Health Initiative Research Program (CHIRP\#64532) to G D. A $B$ was supported by the Intramural Research Program number NS002945 of the NINDS, NIH, Bethesda, MD, to Kenton J Swartz. The opinions expressed here are those of the authors and should not be construed as official or reflecting the views of the Uniformed Services University of the Health Sciences or the Department of Defense. 


\section{Author contribution statement}

$G D, S R$, and $F K$ conceptualized and designed the research. $S R, F K, A B$, and J S B performed the research; S R, F K, A B, J $S B, M L R, S E$, and $G D$ contributed in data interpretation. $S R$ and $G D$ wrote the manuscript, which was revised by all authors.

\section{Acknowledgements}

The authors thank James Warren for his technical contribution and Dr Cara Olsen for assistance with statistical analysis.

\section{References}

Aldo PB, Krikun G, Visintin I, Lockwood C, Romero R \& Mor G 2007 A novel three-dimensional in vitro system to study trophoblast-endothelium cell interactions. American Journal of Reproductive Immunology $\mathbf{5 8}$ 98-110. (https://doi.org/10.1111/j.1600-0897.2007.00493.x)

Alexopoulou AN, Multhaupt HA \& Couchman JR 2007 Syndecans in wound healing, inflammation and vascular biology. International Journal of Biochemistry and Cell Biology 39 505-528. (https://doi.org/10.1016/j. biocel.2006.10.014)

Aronow BJ, Richardson BD \& Handwerger S 2001 Microarray analysis of trophoblast differentiation: gene expression reprogramming in key gene function categories. Physiological Genomics 6 105-116. (https://doi. org/10.1152/physiolgenomics.2001.6.2.105)

Ashton SV, Whitley GS, Dash PR, Wareing M, Crocker IP, Baker PN \& Cartwright JE 2005 Uterine spiral artery remodeling involves endothelial apoptosis induced by extravillous trophoblasts through Fas/FASL interactions. Arteriosclerosis, Thrombosis, and Vascular Biology 25 102-108. (https://doi.org/10.1161/01.ATV.0000148547.70187.89)

Baker M, Robinson SD, Lechertier T, Barber PR, Tavora B, D'Amico G, Jones DT, Vojnovic B \& Hodivala-Dilke K 2011 Use of the mouse aortic ring assay to study angiogenesis. Nature Protocols 7 89-104. (https://doi. org/10.1038/nprot.2011.435)

Ballesteros A, Mentink-Kane MM, Warren J, Kaplan GG \& Dveksler GS 2015 Induction and activation of latent TGF-beta1 is carried out by two distinct domains of pregnancy-specific glycoprotein 1. Journal of Biological Chemistry 290 4422-4431. (https://doi.org/10.1074/jbc. M114.597518)

Basak S \& Duttaroy AK 2013 Effects of fatty acids on angiogenic activity in the placental extravillious trophoblast cells. Prostaglandins, Leukotrienes, and Essential Fatty Acids 88 155-162. (https://doi.org/10.1016/j. plefa.2012.10.001)

Beltrame JS, Sordelli MS, Canumil VA, Franchi AM \& Ribeiro ML 2018 Lysophosphatidic acid-triggered pathways promote the acquisition of trophoblast endovascular phenotype in vitro. Journal of Cellular Biochemistry 119 758-772. (https://doi.org/10.1002/jcb.26239)

Berndt S, Perrier d'Hauterive S, Blacher S, Péqueux C, Lorquet S, Munaut C, Applanat M, Hervé MA, Lamandé N, Corvol P et al. 2006 Angiogenic activity of human chorionic gonadotropin through $\mathrm{LH}$ receptor activation on endothelial and epithelial cells of the endometrium. FASEB Journal 20 2630-2632. (https://doi.org/10.1096/fj.06-5885fje)

Blois SM, Tirado-Gonzalez I, Wu J, Barrientos G, Johnson B, Warren J, Freitag N, Klapp BF, Irmak S, Ergun S et al. 2012 Early expression of pregnancy-specific glycoprotein 22 (PSG22) by trophoblast cells modulates angiogenesis in mice. Biology of Reproduction 86191. (https://doi.org/10.1095/biolreprod.111.098251)

Blois SM, Sulkowski G, Tirado-Gonzalez I, Warren J, Freitag N, Klapp BF, Rifkin D, Fuss I, Strober W \& Dveksler GS 2014 Pregnancy-specific glycoprotein 1 (PSG1) activates TGF-beta and prevents dextran sodium sulfate (DSS)-induced colitis in mice. Mucosal Immunology 7 348-358. (https://doi.org/10.1038/mi.2013.53)

Bohn H 1971 Detection and characterization of pregnancy proteins in the human placenta and their quantitative immunochemical determination in sera from pregnant women. Archiv für Gynakologie 210 440-457. (https://doi.org/10.1007/BF01628222)
Camolotto S, Racca A, Rena V, Nores R, Patrito LC, Genti-Raimondi S \& Panzetta-Dutari GM 2010 Expression and transcriptional regulation of individual pregnancy-specific glycoprotein genes in differentiating trophoblast cells. Placenta 31 312-319. (https://doi.org/10.1016/j. placenta.2010.01.004)

Chen J \& Khalil RA 2017 Matrix metalloproteinases in normal pregnancy and preeclampsia. Progress in Molecular Biology and Translational Science 148 87-165. (https://doi.org/10.1016/bs.pmbts.2017.04.001)

Chen DB, Feng L, Hodges JK, Lechuga TJ \& Zhang H 2017 Human trophoblast-derived hydrogen sulfide stimulates placental artery endothelial cell angiogenesis. Biology of Reproduction 97 478-489. (https://doi.org/10.1093/biolre/iox105)

Chiodelli P, Bugatti A, Urbinati C \& Rusnati M 2015 Heparin/heparan sulfate proteoglycans glycomic interactome in angiogenesis: biological implications and therapeutical use. Molecules 20 6342-6388. (https:// doi.org/10.3390/molecules20046342)

Cole LA 2009 New discoveries on the biology and detection of human chorionic gonadotropin. Reproductive Biology and Endocrinology 78. (https://doi.org/10.1186/1477-7827-7-8)

Conway EM, Collen D \& Carmeliet P 2001 Molecular mechanisms of blood vessel growth. Cardiovascular Research 49 507-521. (https://doi. org/10.1016/s0008-6363(00)00281-9)

De Rossi G \& Whiteford JR 2014 Syndecans in angiogenesis and endothelial cell biology. Biochemical Society Transactions 42 1643-1646. (https:// doi.org/10.1042/BST20140232)

Dimitriadou F, Phocas I, Mantzavinos T, Sarandakou A, Rizos D \& Zourlas PA 1992 Discordant secretion of pregnancy specific beta 1 -glycoprotein and human chorionic gonadotropin by human preembryos cultured in vitro. Fertility and Sterility 57 631-636. (https://doi. org/10.1016/s0015-0282(16)54912-7)

Esko JD \& Linhardt RJ 2009 Proteins that bind sulfated glycosaminoglycans. In Essentials of Glycobiology, 2nd ed. Eds A Varki, RD Cummings, JD Esko, HH Freeze, P Stanley, CR Bertozzi, GW Hart \& ME Etzler. Cold Spring Harbor laboratory press, NY, USA.

Fraser HM \& Lunn SF 2000 Angiogenesis and its control in the female reproductive system. British Medical Bulletin 56 787-797. (https://doi. org/10.1258/0007142001903364)

Fuster MM \& Wang L 2010 Endothelial heparan sulfate in angiogenesis. Progress in Molecular Biology and Translational Science 93 179-212. (https://doi.org/10.1016/S1877-1173(10)93009-3)

Graham CH, Hawley TS, Hawley RG, MacDougall JR, Kerbel RS, Khoo N \& Lala PK 1993 Establishment and characterization of first trimester human trophoblast cells with extended lifespan. Experimental Cell Research 206 204-211. (https://doi.org/10.1006/excr.1993.1139)

Ha CT, Wu JA, Irmak S, Lisboa FA, Dizon AM, Warren JW, Ergun S \& Dveksler GS 2010 Human pregnancy specific beta-1-glycoprotein 1 (PSG1) has a potential role in placental vascular morphogenesis. Biology of Reproduction 83 27-35. (https://doi.org/10.1095/ biolreprod.109.082412)

Hascall V \& Esko JD 2015 Hyaluronan. In Essentials of Glycobiology, pp. 197-206. Eds A Varki, RD Cummings, JD Esko, P Stanley, GW Hart, M Aebi, AG Darvill, T Kinoshita, NH Packer, JH Prestegard et al. Cold Spring Harbor Laboratory press, NY, USA.

Isaka K, Usuda S, Ito H, Sagawa Y, Nakamura H, Nishi H, Suzuki Y, Li YF \& Takayama M 2003 Expression and activity of matrix metalloproteinase 2 and 9 in human trophoblasts. Placenta 24 53-64. (https://doi. org/10.1053/plac.2002.0867)

Islami D, Bischof P \& Chardonnens D 2003 Modulation of placental vascular endothelial growth factor by leptin and hCG. Molecular Human Reproduction 9 395-398. (https://doi.org/10.1093/molehr/ gag053)

Jones K, Ballesteros A, Mentink-Kane M, Warren J, Rattila S, Malech H, Kang E \& Dveksler G 2016 PSG9 stimulates increase in FoxP3+ regulatory T-cells through the TGF-beta1 pathway. PLOS ONE 11 e0158050. (https://doi.org/10.1371/journal.pone.0158050)

Julian J, Das SK, Dey SK, Baraniak D, Ta VT \& Carson DD 2001 Expression of heparin/heparan sulfate interacting protein/ribosomal protein 129 during the estrous cycle and early pregnancy in the mouse. Biology of Reproduction 64 1165-1175. (https://doi.org/10.1095/ biolreprod64.4.1165)

Lala N, Girish GV, Cloutier-Bosworth A \& Lala PK 2012 Mechanisms in decorin regulation of vascular endothelial growth factor-induced human 
trophoblast migration and acquisition of endothelial phenotype. Biology of Reproduction 87 59. (https://doi.org/10.1095/biolreprod.111.097881) Li HY, Chang SP, Yuan CC, Chao HT, Ng HT \& Sung YJ 2003 Induction of p38 mitogen-activated protein kinase-mediated apoptosis is involved in outgrowth of trophoblast cells on endometrial epithelial cells in a model of human trophoblast-endometrial interactions. Biology of Reproduction 69 1515-1524. (https://doi.org/10.1095/biolreprod.103.015669)

Lima PD, Zhang J, Dunk C, Lye SJ \& Croy BA 2014 Leukocyte drivendecidual angiogenesis in early pregnancy. Cellular and Molecular Immunology 11 522-537. (https://doi.org/10.1038/cmi.2014.63)

Lisboa FA, Warren J, Sulkowski G, Aparicio M, David G, Zudaire E \& Dveksler GS 2011 Pregnancy-specific glycoprotein 1 induces endothelial tubulogenesis through interaction with cell surface proteoglycans. Journal of Biological Chemistry 286 7577-7586. (https:// doi.org/10.1074/jbc.M110.161810)

Martinez FF, Cervi L, Knubel CP, Panzetta-Dutari GM \& Motran CC 2013 The role of pregnancy-specific glycoprotein 1a (PSG1a) in regulating the innate and adaptive immune response. American Journal of Reproductive Immunology 69 383-394. (https://doi.org/10.1111/aji.12089)

Mayhew TM, Charnock-Jones DS \& Kaufmann P 2004 Aspects of human fetoplacental vasculogenesis and angiogenesis. III. Changes in complicated pregnancies. Placenta 25 127-139. (https://doi. org/10.1016/j.placenta.2003.10.010)

McLellan AS, Fischer B, Dveksler G, Hori T, Wynne F, Ball M, Okumura K, Moore T \& Zimmermann W 2005 Structure and evolution of the mouse pregnancy-specific glycoprotein (Psg) gene locus. BMC Genomics 64 (https://doi.org/10.1186/1471-2164-6-4)

Mendoza M, Lu D, Ballesteros A, Blois SM, Abernathy K, Feng C, Dimitroff CJ, Zmuda J, Panico M, Dell A et al. 2020 Glycan characterization of pregnancy-specific glycoprotein 1 and its identification as a novel galectin-1 ligand. Glycobiology cwaa034. (https://doi.org/10.1093/glycob/cwaa034)

Meneghetti MC, Hughes AJ, Rudd TR, Nader HB, Powell AK, Yates EA \& Lima MA 2015 Heparan sulfate and heparin interactions with proteins. Journal of the Royal Society, Interface 12 0589. (https://doi.org/10.1098/ rsif.2015.0589)

Moore T \& Dveksler GS 2014 Pregnancy-specific glycoproteins: complex gene families regulating maternal-fetal interactions. International Journal of Developmental Biology 58 273-280. (https://doi.org/10.1387/ ijdb.130329gd)

Nagarajan A, Malvi P \& Wajapeyee N 2018 Heparan sulfate and heparan sulfate proteoglycans in cancer initiation and progression. Frontiers in Endocrinology 9 483. (https://doi.org/10.3389/fendo.2018.00483)

Nakatsu MN, Sainson RC, Aoto JN, Taylor KL, Aitkenhead M, Perez-delPulgar S, Carpenter PM \& Hughes CC 2003 Angiogenic sprouting and capillary lumen formation modeled by human umbilical vein endothelial cells (HUVEC) in fibrin gels: the role of fibroblasts and angiopoietin-1. Microvascular Research 66 102-112. (https://doi.org/10.1016/s00262862(03)00045-1)

Nowak-Sliwinska P, Alitalo K, Allen E, Anisimov A, Aplin AC, Auerbach R, Augustin HG, Bates DO, van Beijnum JR, Bender RHF et al. 2018 Consensus guidelines for the use and interpretation of angiogenesis assays. Angiogenesis 21 425-532. (https://doi.org/10.1007/s10456-018-9613-x)

Peng B, Zhu H, Klausen C, Ma L, Wang YL \& Leung PC 2016 GnRH regulates trophoblast invasion via RUNX2-mediated MMP2/9 expression. Molecular Human Reproduction 22 119-129. (https://doi. org/10.1093/molehr/gav070)

Pijnenborg R, Dixon G, Robertson WB \& Brosens I 1980 Trophoblastic invasion of human decidua from 8 to 18 weeks of pregnancy. Placenta 1 3-19. (https://doi.org/10.1016/s0143-4004(80)80012-9)

Pijnenborg R, Ball E, Bulmer JN, Hanssens M, Robson SC \& Vercruysse L 2006 In vivo analysis of trophoblast cell invasion in the human. Methods in Molecular Medicine 122 11-44. (https://doi.org/10.1385/1-59259989-3:9)

Rattila S, Dunk CE, Im M, Grichenko O, Zhou Y, Yanez-Mo M, Blois SM, Yamada KM, Erez O, Gomez-Lopez N et al. 2019 Interaction of pregnancyspecific glycoprotein 1 with integrin a5b1 is a modulator of extravillous trophoblast functions. Cells 8 1369. (https://doi.org/10.3390/cells8111369)

Redman CW \& Sargent IL 2005 Latest advances in understanding preeclampsia. Science 308 1592-1594. (https://doi.org/10.1126/ science.1111726)
Renaud SJ, Kubota K, Rumi MA \& Soares MJ 2014 The FOS transcription factor family differentially controls trophoblast migration and invasion. Journal of Biological Chemistry 289 5025-5039. (https://doi.org/10.1074/ jbc.M113.523746)

Reppetti J, Reca A, Seyahian EA, Medina Y, Martinez N, Szpilbarg N \& Damiano AE 2020 Intact caveolae are required for proper extravillous trophoblast migration and differentiation. Journal of Cellular Physiology 235 3382-3392. (https://doi.org/10.1002/jcp.29226)

Reynolds LP, Caton JS, Redmer DA, Grazul-Bilska AT, Vonnahme KA, Borowicz PP, Luther JS, Wallace JM, Wu G \& Spencer TE 2006 Evidence for altered placental blood flow and vascularity in compromised pregnancies. Journal of Physiology 572 51-58. (https://doi.org/10.1113/ jphysiol.2005.104430)

Reynolds LP \& Redmer DA 2001 Angiogenesis in the placenta. Biology of Reproduction 64 1033-1040. (https://doi.org/10.1095/ biolreprod64.4.1033)

Rizov M, Andreeva P \& Dimova I 2017 Molecular regulation and role of angiogenesis in reproduction. Taiwanese Journal of Obstetrics and Gynecology 56 127-132. (https://doi.org/10.1016/j. tjog.2016.06.019)

Roberts RM, Green JA \& Schulz LC 2016 The evolution of the placenta. Reproduction 152 R179-R189. (https://doi.org/10.1530/REP-16-0325)

Rudd TR, Preston MD \& Yates EA 2017 The nature of the conserved basic amino acid sequences found among 437 heparin binding proteins determined by network analysis. Molecular Biosystems 13 852-865. (https://doi.org/10.1039/c6mb00857g)

Ruoslahti E 1991 Integrins. Journal of Clinical Investigation 87 1-5. (https:// doi.org/10.1172/JCI114957)

Sarkar A \& Desai UR 2015 A simple method for discovering druggable, specific glycosaminoglycan-protein systems. Elucidation of key principles from heparin/heparan sulfate-binding proteins. PLOS ONE $\mathbf{1 0}$ e0141127. (https://doi.org/10.1371/journal.pone.0141127)

Sarrazin S, Lamanna WC \& Esko JD 2011 Heparan sulfate proteoglycans. Cold Spring Harbor Perspectives in Biology 3 a004952. (https://doi. org/10.1101/cshperspect.a004952)

Shanley DK, Kiely PA, Golla K, Allen S, Martin K, O'Riordan RT, Ball M, Aplin JD, Singer BB, Caplice N et al. 2013 Pregnancy-specific glycoproteins bind integrin alphallbbeta 3 and inhibit the plateletfibrinogen interaction. PLOS ONE 8 e57491. (https://doi.org/10.1371/ journal.pone.0057491)

Sherer DM \& Abulafia O 2001 Angiogenesis during implantation, and placental and early embryonic development. Placenta 22 1-13. (https:// doi.org/10.1053/plac.2000.0588)

Smock RG \& Meijers R 2018 Roles of glycosaminoglycans as regulators of ligand/receptor complexes. Open Biology 8 180026. (https://doi. org/10.1098/rsob.180026)

Sokolov DI, Lvova TY, Okorokova LS, Belyakova KL, Sheveleva AR, Stepanova OI, Mikhailova VA \& Sel'kov SA 2017 Effect of cytokines on the formation tube-like structures by endothelial cells in the presence of trophoblast cells. Bulletin of Experimental Biology and Medicine $\mathbf{1 6 3}$ 148-158. (https://doi.org/10.1007/s10517-017-3756-4)

Straszewski-Chavez SL, Abrahams VM, Alvero AB, Aldo PB, Ma Y, Guller S, Romero R \& Mor G 2009 The isolation and characterization of a novel telomerase immortalized first trimester trophoblast cell line, swan 71. Placenta 30 939-948. (https://doi.org/10.1016/j.placenta.2009.08.007)

Sulkowski GN, Warren J, Ha CT \& Dveksler GS 2011 Characterization of receptors for murine pregnancy specific glycoproteins 17 and 23 . Placenta 32 603-610. (https://doi.org/10.1016/j.placenta.2011.05.008)

Teglund S, Olsen A, Khan WN, Frangsmyr L \& Hammarstrom S 1994 The pregnancy-specific glycoprotein (PSG) gene cluster on human chromosome 19: fine structure of the 11 PSG genes and identification of 6 new genes forming a third subgroup within the carcinoembryonic antigen (CEA) family. Genomics 23 669-684. (https://doi.org/10.1006/ geno.1994.1556)

Teng YH, Aquino RS \& Park PW 2012 Molecular functions of syndecan-1 in disease. Matrix Biology 31 3-16. (https://doi.org/10.1016/j. matbio.2011.10.001)

Torry DS, Leavenworth J, Chang M, Maheshwari V, Groesch K, Ball ER \& Torry RJ 2007 Angiogenesis in implantation. Journal of Assisted Reproduction and Genetics 24 303-315. (https://doi.org/10.1007/ s10815-007-9152-7) 
Towler CM, Horne CH, Jandial V, Campbell DM \& MacGillivray I 1976 Plasma levels of pregnancy-specific beta1-glycoprotein in normal pregnancy. British Journal of Obstetrics and Gynaecology 83 775-779. (https://doi.org/10.1111/j.1471-0528.1976.tb00743.x)

Verkaar F, van Offenbeek J, van der Lee MMC, van Lith LHCJ, Watts AO, Rops ALWMM, Aguilar DC, Ziarek J, van der Vlag J, Handel TM et al. 2014 Chemokine cooperativity is caused by competitive glycosaminoglycan binding. Journal of Immunology 192 3908-3914. (https://doi.org/10.4049/jimmunol.1302159)

Wang H, Wang T, Dai L, Cao W, Ye L, Gao L, Zhou B \& Zhou R 2018 Effects of CXCL3 on migration, invasion, proliferation and tube formation of trophoblast cells. Placenta 66 47-56. (https://doi.org/10.1016/j. placenta.2018.05.004)

Warren J, Im M, Ballesteros A, Ha C, Moore T, Lambert F, Lucas S, Hinz B \& Dveksler G 2018 Activation of latent transforming growth factorbeta1, a conserved function for pregnancy-specific beta 1-glycoproteins. Molecular Human Reproduction 24 602-612. (https://doi.org/10.1093/ molehr/gay044)

Worsdorfer P, Mekala SR, Bauer J, Edenhofer F, Kuerten S \& Ergun S 2017 The vascular adventitia: an endogenous, omnipresent source of stem cells in the body. Pharmacology and Therapeutics 171 13-29. (https:// doi.org/10.1016/j.pharmthera.2016.07.017)

Wurz H, Geiger W, Kunzig HJ, Jabs-Lehmann A, Bohn H \& Luben G 1981 Radioimmunoassay of SP1 (pregnancy-specific beta1-glycoprotein) in maternal blood and in amniotic fluid normal and pathologic pregnancies. Journal of Perinatal Medicine 9 67-78. (https://doi. org/10.1515/jpme.1981.9.2.67)

Yanagishita M \& Hascall VC 19921992 cell surface heparan sulfate proteoglycans. Journal of Biological Chemistry 2679451-9454.
Zhang XA, Bontrager AL \& Hemler ME 2001 Transmembrane-4 superfamily proteins associate with activated protein kinase $\mathrm{C}$ (PKC) and link PKC to specific beta(1) integrins. Journal of Biological Chemistry 276 25005-25013. (https://doi.org/10.1074/jbc.M102156200)

Zhou GQ \& Hammarstrom S 2001 Pregnancy-specific glycoprotein (PSG) in baboon (Papio hamadryas): family size, domain structure, and prediction of a functional region in primate PSGs. Biology of Reproduction 64 90-99. (https://doi.org/10.1095/biolreprod64.1.90)

Zhou GQ, Baranov V, Zimmermann W, Grunert F, Erhard B, MinchevaNilsson L, Hammarstrom S \& Thompson J 1997a Highly specific monoclonal antibody demonstrates that pregnancy-specific glycoprotein (PSG) is limited to syncytiotrophoblast in human early and term placenta. Placenta 18 491-501. (https://doi.org/10.1016/01434004(77)90002-9)

Zhou Y, Fisher SJ, Janatpour M, Genbacev O, Dejana E, Wheelock M \& Damsky CH 1997b Human cytotrophoblasts adopt a vascular phenotype as they differentiate. A strategy for successful endovascular invasion? Journal of Clinical Investigation 99 2139-2151. (https://doi.org/10.1172/ JCI119387)

Received 26 March 2020

First decision 26 May 2020

Revised Manuscript received 28 July 2020

Accepted 20 August 2020 